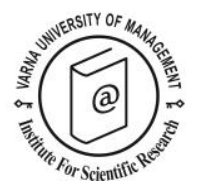

\title{
Marketing perceptions of national and nature parks managers - the case of Croatia
}

\author{
Durdana Ozretic-Dosen ${ }^{1 *}$, Kristina Malesevic ${ }^{2}$, Tanja Komarac ${ }^{3}$ \\ and Vatroslav Skare ${ }^{4}$
}

Received: 14/03/2019 Accepted: 19/06/2019

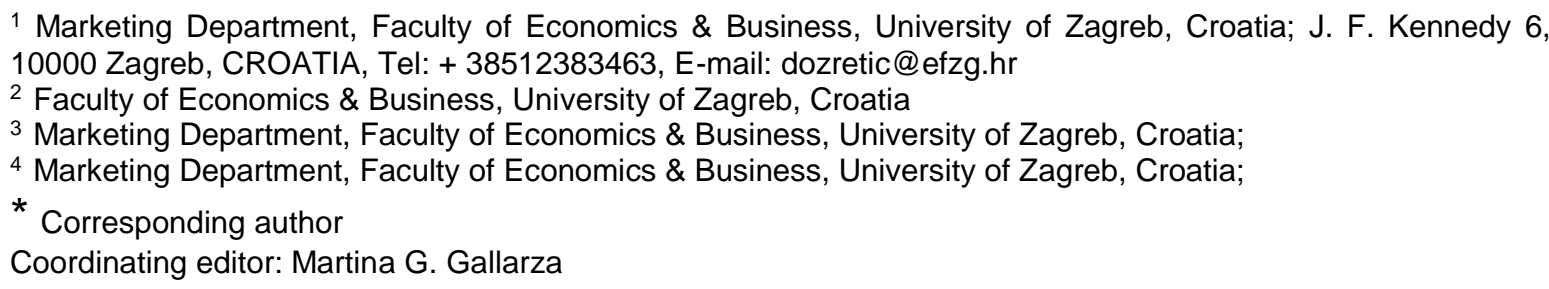

\section{Abstract}

The purpose of this paper is to explore the perceptions of Croatian national and nature parks managers of the current role of marketing in creating and managing parks' offer. Through identifying and evaluating the scope and importance of marketing in national and nature parks, the paper also aims to reveal the possibilities for improving existing practices. The theoretical framework includes a review of contributions from the fields of marketing in national and nature parks' changing environment and the literature on place branding in tourism. Exploratory qualitative research was conducted. An in-depth analysis of secondary data collected from internal materials, print media, and internet resources preceded to a content analysis of primary data collected through personal, semi-structured interviews with 15 key informants. The overall results suggest that umbrella branding emerges as a novel and promising approach. In some cases, the role of marketing in responding to changes in the competitive tourism environment is acknowledged, while in others not, as conservative parks are primarily focused on protection and conservation, which results in fewer resources to implement active marketing management. Research limitations are related to single informant bias and the subjective nature of data (the perceptions of respondents). To the best of the authors' knowledge, the study is the first that enables insight into the umbrella branding approach in the frame of the marketing management of national and nature parks. It brings evidence from one of the Central and Eastern European markets, a domain in which the role of marketing in national and nature parks has been under-researched.

Keywords: national and nature parks, marketing, umbrella branding, marketing mix, Croatia

Citation: Ozretic-Dosen, D., K. Malesevic, T. Komarac and V. Skare (2019) Marketing perceptions of national and nature parks managers - the case of Croatia. European Journal of Tourism Research 23, pp. 191-207

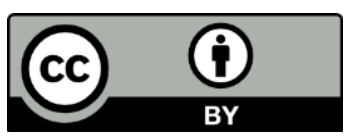

RESEARCH PAPER
This work is licensed under the Creative Commons Attribution 4.0 International (CC BY 4.0). To view a copy of this license, visit https://creativecommons.org/licenses/by/4.0/ 


\section{Introduction}

Protected areas attract visitors and are considered an important element of the destination image and competitiveness. National and nature parks, as a protected area category (International Union for Conservation of Nature (IUCN), 2018) represent appealing and interesting attractions which deliver unique experiences to domestic and foreign visitors. It is widely recognized that they contribute to the image formation and attractiveness of tourism destinations. According to Nogueira and Pinho (2015), different types of special-interest tourism (SIT) record continuous growth; national and nature parks are places where many activities characteristic for the particular kind of special-interest tourism can be practiced. Visiting national and nature parks offers many high value-in-use activities (e.g., hiking, climbing, diving, sailing, enjoying landscapes, birdwatching, etc.) which through visitors' recreation, according to the experience economy paradigm (Pine and Gilmore, 1998) enable entertainment, education, escapism and aesthetic effects simultaneously.

The purpose of this study is to investigate, identify and evaluate the role and importance of marketing in national and nature parks in Croatia, the country with a long tourism history that nowadays heavily relies on natural heritage for (re)shaping its tourism destination image. As stated in the official data of the Ministry of Tourism of the Republic of Croatia (MINT, 2018): "In the last six years Croatia's 11 nature parks and eight national parks registered 17.4 million visitors, and in 2017 alone there were four million tourists in those destinations." National and nature parks represent the unique quality of Croatia as a tourist destination, but their potential is far from being fully exploited. Although parks vary in types of natural attractions, size and visitors, achieving an overall differentiation and the better image should be one of the primary goals of their tourism marketing management.

The main aim of the study is to explore qualitatively the perceptions of Croatian national and nature parks managers of the current role of marketing in creating and managing parks' offer in order to reveal the possibilities for improving existing practices.
The qualitative exploratory research approach was chosen because it allows interpreting knowledge of a chosen topic, according to the thorough study of perceptions, opinions, and perspectives of experienced key individuals (Snow and Thomas, 1994), aiming to describe the development of the phenomena in the particular context (Croatian national and nature parks).

From the theoretical perspective, this study has two aims related to addressing gaps in the literature. The first aim is to shed light on the umbrella branding research issue, which was not, to the best of authors' knowledge, the subject of academic research in the context of marketing national and nature parks. Secondly, the study aims to add to the existing knowledge, by contributing to the research from the new context (Central and Eastern Europe CEE, Croatia) which has been underresearched so far.

From the managerial perspective, findings can help managers in parks to improve marketing decision-making, and better meet the coexisting goals: fulfilling visitors' expectations, protection of nature and community development.

After the introduction, a brief theoretical framework, focusing mainly on contributions about marketing in national and nature parks' changing environment and place branding in tourism is presented. A description of the methodology and approaches to data collection follows. Findings and analysis of the results of primary research are summarized in the further section. Finally, conclusions, implications, research limitations and recommendations for future research are presented.

\section{Theoretical background and research questions}

A considerable amount of research (e.g., Hogenauer, 2002; Nan-Hwang et al., 2005; Gilmore, and Simmons, 2007; Sharpley and Pearce, 2007; Reid et al., 2008; Mayer et al., 2010; Haukeland, 2011; Schwartz et al., 2012; Eagles, 2014; Barić et al., 2016; Douglas, 2016) has been devoted to examining different marketing and management aspects in natural and nature parks, and reveals relevant and 
interesting findings. However, as stated by Ortega (2009) most of the research is dedicated to the one or several parks from one country, while the research examining all parks in one country, or comparative research among parks in two or more countries is still scarce.

Historically, one of the reasons for the restrained or even hostile attitude toward marketing in the national and nature parks, as claimed by Archer and Wearing (2002), has been a relatively short history of marketing within the public sector. Due to the prevailing attitude that the resource preservation was a priority and visitors were of the second order in importance, marketing in the parks, according to Hogenauer (2002), should take into consideration traditional approach and methods, applied in the specific context of protected areas.

Analysing development and impacts of the two decades of joint management of national parks in Australia, Smyth (2001) has outlined the potential advantages and disadvantages for all stakeholders, including park visitors. Gilmore and Simmons (2007) advocate for a strategic approach and integration of sustainable marketing and management, in order to harmonize the attractiveness of the national and nature parks for tourism demand and the need to prevent detrimental impact which the increased number of visitors may have on protected areas. In reporting research results about the work of the English National Park Authorities, Sharpley and Pearce (2007) stress how parks' authorities still suffer from a fundamental misunderstanding of the role of marketing, which prevents them in its wider and deeper implementation for sustainable tourism development. This may be corroborated by the research results of Mayer et al. (2010), who found the disproportion between the number of potential and actual visitors of high national park affinity, which implies insufficient marketing efforts regarding promotion, common branding and alike.

The relationship between tourism and the environment is getting closer because of a growing concern for the conservation of protected natural areas (Deffner and Metaxas, 2009). A large number of environmentally conscious people consider choosing national and nature parks for a vacation destination to be a "good buy" (Yellowstone Country Montana - Marketing Plan, 2011). When examining the influence of twelve push and twelve pull factors, Kim et al. (2003) have found how four push factors (family togetherness and study; appreciating natural resources and health; escaping from everyday routine and adventure; and building friendship) and three pull factors (key tourist resources; information and convenience of facilities and accessibility; and transportation) are the most influential on decisions to visit Korean National Parks. Also, Kruger and Saayman (2010, p. 4) pinpoint the role which different motives for visitation have on the satisfaction of visitors and recommend positioning national and nature parks in line with "the concept of a place to escape and relax." No matter of their specific motives, all visitors to national and nature parks pay attention to several key aspects - fun and freedom, naturalness and authenticity (Baltic Sea Region Programme, 2012).

Eagles (2014) warns about the insufficient research in park tourism and outlines ten priorities connected with the existing and significant research gaps. Priority areas include (Eagles, 2014, p. 529) "(1) Visitor use monitoring; (2) Park tourism economic impact monitoring; (3) Park finance; (4) Professional competencies for tourism management; (5) Building public support; (6) Visitor satisfaction; (7) Licences, permits, leases, and concessions for tourism; (8) Pricing policy; (9) Management capacity; and (10) Park tourism governance." All ten areas are interrelated while five among them are closely connected to marketing management in parks. They are: visitor use monitoring, professional competences for tourism management, visitor satisfaction, management capacity and pricing policy.

Relying on the presented theoretical contributions and the results of previous research, this study aims to explore whether marketing and marketing management have a similar or different role and characteristics in national and nature parks in Croatia. Therefore, the two following, specific research questions were posed: 
RQ1: What is the role of marketing in the national and nature parks of the Republic of Croatia?

RQ2: What is the role of competition in the (marketing) management of national and nature parks in the tourist industry of the country?

For Destination Management Organization (DMO) branding represents the powerful way for the creation and communication of the clear identities to targeted markets, which ensures positioning and differentiation based on a clear image (Ren and Blichfeldt, 2011). In line with the previous empirical and experimental evidence (e.g., Erdem, 1998; Iversen and Hem, 2008; Miklós-Thal, 2012; Kooli et al., 2016), the umbrella branding is considered a guarantee of quality, has signalling effects, enables an increased demand and helps to build loyalty. Gnoth (2007) states that when deciding on the attributes of the umbrella brand, destination managers are challenged by two requirements: competitive brand positioning and easy identification, i.e., distinctiveness.

In general, national and nature parks have marketing programs on an individual basis, the analysis of which mainly reveals rather similar strategies. Therefore, the umbrella branding might offer multiple possibilities in order to achieve the better competitiveness, distinctive positioning and improve market shares. As put forth by Flagestad and Hope (2001), by exploiting the existing similarities, the strategic approach of umbrella branding may have particular benefits regarding differentiation from competitors. However, the relationship and differentiation among brands under the same umbrella (the brand architecture) should not be overlooked. To the best of the authors' knowledge, there is no academic research dedicated to the role of the umbrella branding in the context of tourism in national and nature parks. Further research is needed, which is why the following research question was posed:

RQ3: What is the role of the umbrella brand Parks of Croatia - in building the image of the Croatia as a tourist destination?

National and nature parks characteristics have values, which influence the overall perception of a country as a tourism destination. Parks authorities, visitors, and the community have expectations of transforming those values into positive business results, both financial (revenues) and non-financial (customer satisfaction). Currently, governmental support for parks in many countries, including Croatia, is modest. Resources which each park has for marketing are scarce and limited; therefore, different and innovative approaches for better business results are needed. Furthermore, parks share many common marketing management challenges that are related to the: customer i.e., visitor care; pricing policy; servicescapes; demand and offer (capacity) management; service delivery channel design (e.g., web, mobile devices and applications for ticketing and booking services), internal and external marketing communications. In an attempt to understand better the role and implications that managers assign to marketing mix elements, the fourth research question was:

RQ4: How is the process of creation and management of the marketing mix elements carried out?

\section{Methodology}

Exploratory research was conducted in the setting of the national and nature parks of the Republic of Croatia in order to uncover and investigate the actual, contemporary challenges related to marketing issues. The aim was to provide theoretical insights and practical suggestions, which could help marketing academics and professionals to understand better and deal with the potential opportunities and threats in the parks' market environment.

In line to include in the research the respondents from all parks in the country, the invitation to participate was sent to all 19, i.e., to 8 national and 11 nature parks. Key professionals (marketing managers or general managers) were chosen because of their knowledge, experience, and influence on parks' strategies and operations. Initial contact was made by letter to general managers, sent by email. They were informed about the purpose and objectives of the research and were asked to participate. A reminder e-mail message was 
sent to those who did not reply. The consent to participate in the study gave 17 , and the final sample included 15 parks. Since the researchers intended to interview only one respondent in each park (marketing manager or in the absence of an employee with that job, a general manager), after initial contact in those parks that agreed to participate, it was decided who would be the respondent in the research. Depending on the organizational complexity and division of jobs in every park, the person responsible for marketing activities or general manager was selected. Getting in contact with the selected respondent followed and the details of the interviewing term were agreed on. A qualitative research approach was applied. To examine the issues, primary data were collected through personal, semistructured interviews with the key informants. Although the interviewing method relies heavily on the opinions, perspectives, and recollections of respondents, it was chosen because it allows an in-depth examination of phenomena (Snow and Thomas, 1994).

Interviews lasted between 30-45 minutes each, and they were conducted from December 2015 to March 2016. Ten interviews were conducted face-to-face, the remainder by telephone for the reasons of convenience. One researcher, without the presence of the other coresearchers, conducted all interviews.

Data were collected by employing semistructured interviews with general managers of the parks or the person responsible for marketing activities. From 15 interviews, eight were conducted with the general managers of parks and seven with the persons in charge of marketing. Demographic characteristics of respondents are shown in Table 1. Additionally, the sample was composed of respondents having five different academic backgrounds: 7 in economics \& business economics, 3 in biology, 2 in agronomy, 2 in politology and 1 in forestry engineering.

All respondents who agreed to participate in the research expressed their willingness to answer all the questions. Respondents were guaranteed complete anonymity. The interviews commenced with a general question about the park and marketing in the park. The purpose of this approach was to leave to the respondents to initiate a discussion on the topics related to marketing activities and to speak freely on the subject. Later on, the conversation was steered toward the relevant issues, which were selected based on the previous literature review and the identified research gaps: the roles of marketing and competition, umbrella branding initiative of national and nature parks in the Republic of Croatia and the process of creation and management of the marketing mix elements. Figure 1 shows a diagram of interview steps, depicting topics discussed with the respondents.

Table 1. Demographic characteristics of respondents

\begin{tabular}{lll}
\hline Respondents & Gender & Age \\
\hline P-01 & F & Within $21-30$ years \\
P-02 & M & Within $31-40$ years \\
P-03 & M & Within $31-40$ years \\
P-04 & M & Within $41-50$ years \\
P-05 & F & Within $31-40$ years \\
P-06 & M & Within $31-40$ years \\
P-07 & M & Within $51-60$ years \\
P-08 & F & Within 21-30 years \\
P-09 & F & Within $31-40$ years \\
P-10 & F & Within $31-40$ years \\
P-11 & M & Within $41-50$ years \\
P-12 & F & Within $41-50$ years \\
P-13 & F & Within 21-30 years \\
P-14 & M & Within $51-60$ years \\
P-15 & F & Within $31-40$ years \\
\hline
\end{tabular}

Source: Research

All the interviews were recorded, and transcripts were made. Each participant is randomly assigned a tag (from P01 to P15). Collected data were content-analysed. The direct content analysis (Hsieh and Shannon, 2005) was used as an appropriate approach because it allows the further description of a phenomenon whose research is incomplete, by combining key concepts from the existing theory and prior research (as predetermined categories for formulation of open-ended questions), with developing additional, new categories based on detailed and careful transcripts analysis. As explained by Lune and Berg (2017: 183-184) "The code categories reflect the meanings and expectations inherent in the theoretical framework that the researcher has adopted in order to view the study." A list of codes was developed, enabling transformation 


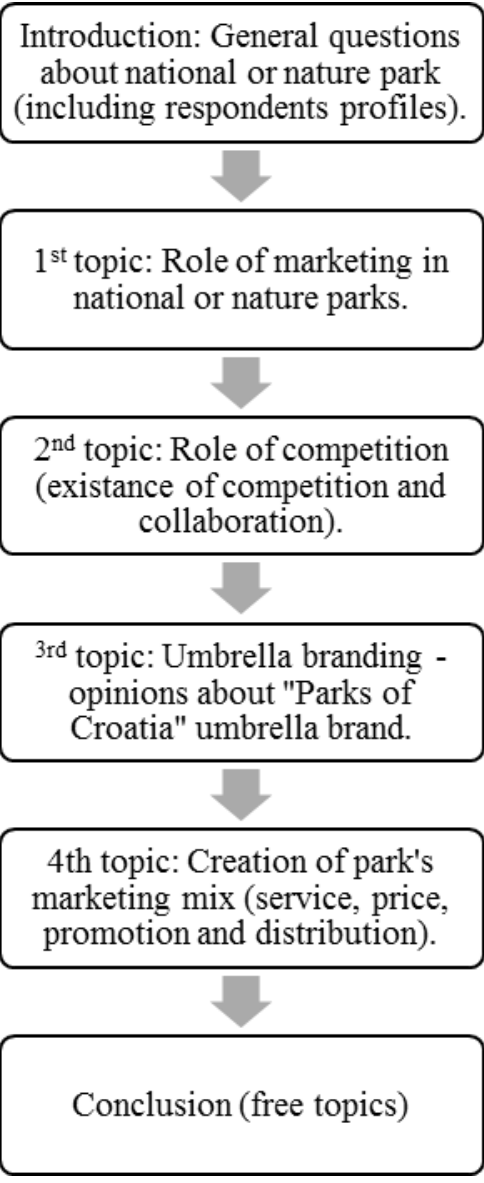

Figure 1. Diagram of interview steps

and reduction of data to classify and build categories. Three researchers out of four (except the one who conducted interviews) coded the data. The process of coding included three steps (Daymon and Holloway, 2002): fragmenting the data, putting data back together in new ways, and selecting a core category. Secondary data (information gathered by literature review) was coded first, then data from primary research. During the process, thematic categories derived from the literature review were complemented by the new codes created from primary research. The process of coding went through several iterations in order to avoid repeating and/or losing information. Final dimensions, categories, and subcategories are shown in Table 2. In addition to interview transcripts, for the purpose of the data triangulation, the analysis included secondary written and audiovisual data collected from internal materials (parks archival data) provided by respondents, and from print media (newspapers and magazines, parks brochures and other promotional materials, publications of the Ministry of Tourism and internet resources web postings). Investigator triangulation (Decrop, 1999) was performed as well; four researchers worked in two teams to interpret the same collected body of data. Data triangulation and investigator triangulation assure that the research has internal validity. In terms of reliability, the researcher who interviewed used the same instrument (semi-structured interview guidelines) and procedure in collecting data from informants; secondary data and data from transcripts are included in an extensive and complete database.

\section{Findings and analysis}

Four critical topics, framed by the research questions, emerged from the interviews. In data analysis and elaboration, respondents' quotes

Table 2. Dimensions, categories, and subcategories - results of coding

\begin{tabular}{ll}
\hline Dimensions & Categories \& Subcategories \\
\hline Marketing in national and & $\begin{array}{l}\text { Definition of marketing (Promotion, Sales, Marketing communications) } \\
\text { narketing department (Education and training in marketing) } \\
\text { Marketing planning (Formal marketing plan) }\end{array}$ \\
$\begin{array}{l}\text { Competition and } \\
\text { cooperation on the tourism } \\
\text { market }\end{array}$ & $\begin{array}{l}\text { Competition (between parks, between parks and other tourist } \\
\text { attractions) } \\
\text { Destination(s) branding }\end{array}$ \\
$\begin{array}{l}\text { Cooperation (between parks, between parks and other tourist attractions } \\
\text { Individual vs. Umbrella branding (brand "Parks of Croatia", perceived } \\
\text { of service offer }\end{array}$ & $\begin{array}{l}\text { benefits) } \\
\text { Segmentation and targeting, resources and challenges related to }\end{array}$ \\
\hline
\end{tabular}


obtained during interviews are used for the illustration, too.

1. Prevailing interpretation of marketing in national and nature parks

Respondents claim they understand the importance of marketing, especially for attracting visitors and creating the park's services offer. However, most of them put forth promotion or even identified it with the concept of marketing.

"The goal and role of marketing in the park is to attract new visitors, to provide new services and to retain the visitors through delivering satisfaction." (P14)

"Marketing is very important in every park. Through the good promotion of the park, there is an increase in the number of visitors, which through the rise in revenues opens up the possibility of better monitoring, inventory, and protection of the park, while also providing income for the local community through new employment and the visitors' consumption." (P03)

"Marketing primarily promotes the fundamental task of the park, which is to protect nature and the environment, preserve essential habitats and animal and plant species." (P15)

Marketing planning is insufficient, and many parks do not have a marketing plan (P01, P04, P09 and P14). In most cases (P03, P08, P10, $\mathrm{P} 11, \mathrm{P} 12$, and $\mathrm{P} 13)$, marketing related activities are set out in the management plan. Two respondents (P02 and P06) said that they have a one-year marketing plan, while one respondent (P05) replied:

"Marketers could systematically plan only to a certain extent because of the turbulent tourism market."

Marketing department exists in the organizational structure of two parks (P02 and P08). Marketing activities in other parks are carried out by the "Department of tourism" (P01 and P05), "Department of tourism, promotion, presentation and catering "(P13), "Publicity, sales, and tourism industry" (P03 and P09), and "Department for technical tasks of protection, maintenance, preservation, promotion and use" (P10). The most common reasons for the absence of a formal marketing department and the lack of implementation of marketing activities are a shortage of financial resources, the greater orientation towards protection of nature or construction of infrastructure.

"Marketing has not received the appropriate significance within the division of work in our park yet, because we are still focused on building a necessary infrastructure ... the question is when we will be able to set up a marketing department or hire a marketing expert." (P11)

Investing in marketing education and training is extremely modest. It is present in eight parks only and consists of attending lectures and workshops (P01, P02, P03, P05, P07, P10, $\mathrm{P} 13$, and $\mathrm{P} 14)$.

"Given the lack of funds, both those from the Ministry and own, there are not investments in educating employees in the marketing area." (P09)

Most respondents think that marketing activities are not sufficiently developed and there is much room for the improvement. They believe that marketing is of great importance for the parks' future, and affirm the need to invest much more in it. All respondents agree that marketing communications should be extremely important for all levels of relationships: with visitors, local population, among colleagues within the park and the parks.

2. Opinions of natural and nature parks managers about competition and cooperation in the tourism market

The overall results related to the $R Q 2$ are surprising. Three respondents (P01, P09, and $P 15)$ identify all other national and nature parks in the country as their competitors. Only one respondent (P02) states:

"Our competitors are also other attractions in the region where the park is located."

All other respondents assert that they have no competition because each park is very specific, unique and as such can not have competitors. 
"In my opinion, the protected area has no competitors; we can have only similar parks, but not competitors." (P03)

The cooperation between the parks is described as being excellent during the several last years. Parks' managers have regular meetings and collaborate on joint projects and promotion. Benchmarking with successful parks in the world is not a common practice in nine parks (P01, P03, P04, P06, P07, P08, $\mathrm{P} 10, \mathrm{P} 11$, and P14). Two respondents (P02 and P05) monitor the activities of the parks in general, while two respondents (P12 and P13) claim to employ benchmarking within certain segments of the business activities. Only two respondents (P9, P15) indicated they follow successful world's parks as their role models.

"We follow the activities of other parks, their successful projects, and good practice, and if possible, we try to apply them in our work. When designing new content or infrastructure, and promotional materials, the first station in searching the ideas on the internet are the websites of parks from abroad. We can mention the Italian parks (Alto Adige region) which we visited to see their visitor centres and the way how they function..." (P09).

Respondents' opinions on the competitive position of parks are divided. Some managers believe that parks should be exclusively oriented to the specific market niche. Others think that cooperation with different tourist attractions and joint efforts to create tourism offer is inevitable. Still, all regard the competitive position of the parks as unsatisfactory claiming that the leading position in the tourist industry belongs to the destinations on the Adriatic coast.

3. Building a destination image under the umbrella brand "Parks of Croatia"

In order to identify how managers reflect on and evaluate the potentials of the umbrella brand, findings related to the RQ3 are analysed separately. The "Parks of Croatia" (Figure 2 and 3) brand and the corresponding visual identity of national and nature parks (Figure 4) were implemented in April 2014, in the frame of the joining the EU Natura 2000. This initiative represents an integral part of the Tourism
Development Strategy of the Republic of Croatia by 2020 . It is a result of efforts to integrate the identity of Croatia (as a tourism destination) with the identities of each of the parks in order to create a common profile and an attractive, unique offer.

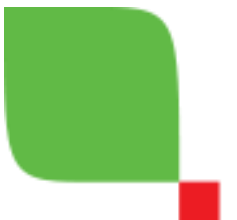

\section{PARKOVI HRVATSKE}

Figure 2. New visual identity of national and nature parks of Croatia

Source: https://www.parkovihrvatske.hr/

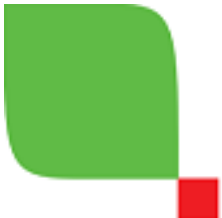

\section{PARKS OF CROATIA}

Figure 3. New visual identity of national and nature parks of Croatia (for english speaking markets)

Source: https://www.parkovihrvatske.hr/about-us

All respondents support and welcome the idea of gathering parks under the same brand. They suppose how such communication strategy will have synergetic effects and help all parks in getting additional recognition and recall.

"This is a relatively new thing and has not yet fully come to fruition. The initiative of putting everything in one place is certainly good; each one of us has its specific value, and this must be set up as special niche, and we must communicate that to the target group ..." (P06)

"The umbrella brand will enable the better promotion of all parks globally, which will certainly affect the image of the Republic of Croatia as a tourist destination." (P01)

Also, the reason for the positive opinion is that:

"The brand will help "small" parks in their promotion.",

as claimed by four respondents (P05, P06, $\mathrm{P} 08$, and P10). Several respondents hope that 


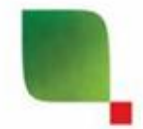

\section{PARKOVI \\ HRVATSKE}

parks of Choatia

MLIJET

\begin{tabular}{|c|c|c|}
\hline siokovo & (5) & (3) Lastoysso \\
\hline S 1 LoNsko & MEDVEDNICA & (0) PAPUK \\
\hline 12 TELAŠćıCA & U UčKA & (1) veLEBIT \\
\hline YRANSKo & 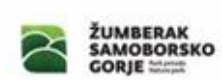 & \\
\hline
\end{tabular}

Figure 4. Croatian and English version of the umbrella brand "Parks of Croatia" Source: https://vizkultura.hr/dizajnirani-jezik-hrvatske-prirode/

the common brand may help in attracting major investments in parks such as in the parks' servicescapes and will thus enable increasing attractiveness and revenues. Even though "Parks of Croatia" brand has been introduced relatively recently, all respondents believe that it will undoubtedly contribute to the creation of the image of a country that cares about nature protection, which will have an impact on the image of Croatia as a tourism destination.

4. Creating services (experiences) offer and marketing mix management

Respondents were asked a series of questions about the process of creating and managing offer and its marketing mix elements. All respondents concentrate on target segments composed of individual tourists and organized groups (hotel guests from the nearby tourism destinations; sports associations, and clubs; pre-school, elementary and high school pupils; college groups; senior citizens, etc.). Also, they claim that visitors have similar motives related to the desire for an active holiday in nature, connection with nature, exploration of the unknown and the like. Segmentation is made only according to specific features of each park, e.g.: mountaineers (P04, P09, P12, P14, and P15), climbers (P03, P04, P09, and P14), sailors (P01, P02, and P07), divers (P01, P02), 
birdwatchers (P06, P11). Although all respondents believe that the visitors' satisfaction is extremely important, they have a very different practical approach for its monitoring and measurement. The lack of human and financial resources is the reason for the absence of satisfaction measurement in three parks (P02, P04, and P07):

"The shortage of money is a problem for introducing formal measurement"; "We do not have qualified employees to perform such a task."

One respondent states (P05) that the park is about to start with the extensive research on visitors' satisfaction. In other parks, instruments used for tracking and measurement of satisfaction include surveys (P01, P03, P06, $\mathrm{P} 09, \mathrm{P} 10, \mathrm{P} 11, \mathrm{P} 12, \mathrm{P} 13$, and P14) and a book of impressions (P01, P08, P09, P11, P12, and $P 15)$. Parks offer services depending on their natural attractions and specificities, e.g., diving (P01, P02, and P05) or bird watching (P06 and $P 11)$. The visitor centre exists in seven parks only (P02, P03, P04, P06, P12, P14, and P15). Hospitality services are offered by hotels in the park (P02, P05, and P12), mountain lodges (P03, P04, P12, P14, and P15) and restaurants (P02, P03, P05, P07, and P14). Additional services - ecological and educational programs were mentioned by four respondents (P04, $\mathrm{P} 10, \mathrm{P} 11$, and $\mathrm{P} 13)$ and services of professional guides by four respondents, too (P02, P05, P08, and P09). Respondents are aware that more, different services are needed for the attraction of visitors.

"We think that an adrenaline park might be an interesting service upgrade."(PO9)

"A playground for children is something we plan to introduce as a new offer." (P14)

Also, respondents list wellness (P02), auto camp (P15), a greater variety of educational programs (P01 and P11), the organization of the education program for elementary school pupils (P06), services and programs adapted for people with disabilities (P08), research workshops (P10) and visitor centre (P03, P04, P07, P08, and P15).
Croatian national and nature parks are public institutions and therefore budget users. Their management teams are appointed by the Croatian Government (Uredba o upravljanju nacionalnim parkovima, NN 59/1991). The ticket price in the parks is shaped by previous market analysis. The entrance fee represents a vital source of income for eleven parks (P01, P02, P03, P05, P06, P07, P08, P10, P11, P13, and $P 14)$, while four parks do not have an entrance fee. Respondents inform that income generated by the tickets and souvenirs sales, extra charged additional services and donations, is invested in the protection of nature, the maintenance of infrastructure, and lastly in promotional materials.

Traditionally, a variety of printed materials is used for promotion.

"We offer promotional materials on several tourist info-points. Furthermore, booklets, tourist maps, guides, and promotional films are regularly distributed at various retail outlets such as bookstores, souvenir shops, mountain huts, etc.". (P08)

Respondents acknowledge that information technology affects tremendously marketing communication.

"We are conducting an internet campaign because we want to be present and enter people's mind. We are proud of our promotional film we show wherever we are at congresses, fairs, film festivals." (P02)

Web sites, virtual tours through the park, interactive maps, and mobile applications are available to visitors.

"Information technology enables visitors, prospective visitors, and all interested in, the whole new experience of the park. Given the technology availability and the everincreasing use of different applications, this type of communication is indispensable." (P01)

"Visitors may use mobile devices instead of paper maps, while the mobile application, in addition to information, helps in orientation in the park." (P12) 
The majority of respondents believe that recently created internet portal of Parks of Croatia (in line with the umbrella branding) will have a positive impact on the promotion of parks, by helping visitors to plan their trip and find useful and interesting information. The portal provides online ticketing and mobile applications which help visitors to navigate through the parks.

Finally, the place/distribution element was analysed. Respondents were asked to express their opinions regarding the orientation toward the priorities: the protection of nature, tourism valorisation of parks' services, and capacity management due to fluctuations in demand. All respondents make clear how the protection of nature is "condicio sine qua non" for the tourism valorisation which comes afterward. Most respondents are convinced that both elements should be balanced.

"Our priority is the protection of nature, and the park's role is to protect endangered species and a whole ecosystem from human influence..." (P05)

"We strive to be in the balance; no tourist development is allowed to have a negative influence on nature." (P08)

"Nature conservation is the primary activity of the park, while tourism valorisation is one of the elements that help the park's greater recognition as an attraction." (P12)

Five respondents report not having problems with fluctuations in demand - the geographical location and climatic conditions enable receiving visitors almost throughout the whole year (P03, P04, P06, P08, and P12). In other parks, increased demand is recorded according to the seasons, e.g., in the mountain parks from spring to autumn (P09, P10, P14, and $\mathrm{P} 15)$, in the parks of the Adriatic Sea region from the beginning of May until the end of October. Parks that are located in the coastal area and on the islands are struggling with the problem of capacity during the summer months (June, July, August) when the number of visitors increases drastically in comparison with the rest of the year (P01, P02, P05, P07, P11, and $P 13)$. In facing an excessive number of visitors, different approaches are used. They include pre-reservations (especially for organized groups of visitors), limitation of the daily number of visitors, the deployment of visitors to different locations in the park, and increased care for the organization of transport to the park and inside the park. Respondents underline that good organization is indispensable in helping to prevent the negative effects which an excessive number of visitors may produce to the natural resources and attractions.

\section{Discussion}

The present study explores how managers view and use marketing in national and nature parks in Croatia. Research results show that the primary orientation of the national and nature parks is the protection of nature and the preservation of those natural and cultural values due to which they were declared a protected area. This finding is not surprising and is in line with previous research results from other contexts, e. g, with those of study undertaken by Sharpley and Pearce (2007) in English national parks.

The growing importance of sustainability and the need for commitment to strategic, systematic and holistic management of different internal and external aspects in national and nature parks are often highlighted findings of prior research (e.g., Cater, 2000, Bosetti and Locatelli, 2006). Statements about topics covered by the first research question show that managers in national and nature parks in Croatia also confirm the tendency and desire towards the dynamic development of economic activities, and are aware of the challenge of how to keep environment protection and commercial activities in the balance. To that end, they acknowledge that more extensive and professional use of marketing would be a desirable way to achieve both goals in the future. They put forth a priority of avoiding conflicts between the nature conservation and tourist valorisation. Besides, they advocate an appropriate organization and marketing management of park activities regarding both nature protection and economic efficiency, with shared resources.

National and nature parks are positioned vis-àvis each other, and vis-à-vis other tourism attractions in the Republic of Croatia; they are 
both competitors and collaborators. Wang and Krakover (2008) have underlined the coexistence of competitive and collaborative relationships among tourism stakeholders in a destination and pinpointed that the perceived relationship between competition and collaboration has a significant role for destination marketing. Contrary to that, research findings regarding issues related to competition (the second research question) have revealed that most of the managers in Croatian national and nature parks are not fully aware of such a situation. They claim to have a budget which is insufficient for gaining and maintaining a sustainable competitive advantage. Unfortunately, they do not distinguish the types of competition adequately. Furthermore, they hesitate to search for alternative and innovative marketing management approaches. All this points to the lack of managerial competencies for strategic destination marketing.

Managers have shown the most consistent match in responses regarding the characteristics, advantages, and potential of the umbrella brand "Parks of Croatia" (topics framed by the third research question). All respondents want to keep individuality and traditions of parks but are not against the brand architecture, where the umbrella brand might provide positive and synergetic effects. They recognize the need for planned and coordinated activities which will enable individual brands to fit well under the umbrella brand. This finding supports and contributes to those of Datzira-Masip and Poluzzi (2014) who have called for much more developed and reinforced application and management of the tourism brand architecture concept. Although "Parks of Croatia" brand covers a range of different national and nature parks, managers are certain of its significant potential to build relationships with visitors. They mention it as a point of reference for consulting about different issues related to elements of the marketing mix, too. Therefore, it can be concluded that managers find the umbrella brand as an appropriate means for building and coordination of a common identity of national and nature parks and its communication to different audiences. These results are in line with previous research (e.g., Dooley and
Bowie, 2005; Therkelsen and Halkier, 2008; Hankinson, 2010; Ren and Blichfeldt, 2011) that favour communication of a uniform message about a strong place profile, which enables standing out among competitors and creation of the emotional bond between the brand and its stakeholders. This approach is, above all, interesting for smaller parks, the managers of which ask for more cooperation, trust and joint initiatives among independent partners. This finding corroborates those of Kooli et al. (2016) who have found a similar situation in the context of German hospitality industry.

Results have discovered that the marketing mix is seen to be the most comprehensive and complex management issue (the themes include in the fourth research question). Managers have reported the use of very traditional approaches and tools in designing the service offer and marketing mix elements. This reflects lagging behind contemporary experiential marketing, which, according to Schmitt (1999, p. 26), "is necessary to move from the features-and-benefits approach toward marketing to the customer experience." Managers' reluctance for embracing more proactive and advanced approaches (e.g. in segmentation, targeting, new services design, customer satisfaction and service quality measurement, etc.) represents a clear constraint for successful performance, both from the short and long-term perspectives. When it comes to financial aspect and pricing policy, results support prior research findings (e.g. in Eagles and McCool, 2002); funding is composed mainly of government funding and entrance fees, with souvenir sales and donations to a lesser extent.

Research results show that respondents recognize the importance of applying information technology in their everyday business and especially for communication with target audiences. This finding validates the prior one, found by Koliouskaa and Andreopouloua (2013), that the use of ICT represents a very important step for the promotion of protected areas with natural and cultural importance. 
Table 3. Three groups of national and nature parks in Croatia, with different approaches and characteristics in relation to the level and coverage of application of marketing management

\begin{tabular}{|c|c|}
\hline Group & Main characteristics \\
\hline $\begin{array}{l}\text { 1. "Marketing-minded" } \\
\text { parks } \\
\text { 2. Parks lacking } \\
\text { resources for marketing } \\
\text { activities }\end{array}$ & $\begin{array}{l}\text { - recognition of marketing and marketing management, marketing is to a } \\
\text { certain extent implemented in everyday management practice } \\
\text { - national and nature parks managers understand the need for proactive } \\
\text { marketing, marketing activities are desirable, but parks are lacking adequate } \\
\text { resources }\end{array}$ \\
\hline
\end{tabular}

Source: Research

Regarding the place/distribution element of the marketing mix, and more specifically the need to harmonize protection of nature with the services offered and capacity management, results have pointed to many connected and to some extent overlapping areas that need continuous monitoring and improvement. As such, results emphasize the relevance of Eagles' (2014) findings regarding research priorities in park tourism.

Conclusive results regarding the marketing mix elements indicate that, despite efforts and commitment, managers lack knowledge and skills to cope successfully with challenges they have to face. As argued by Sharpley and Pearce (2007), such a situation represents a serious barrier for effective tourism marketing management. Nevertheless, it is important to stress that conducting marketing activities is only one part of the job description of the respondents. Doing marketing in the public sector has a much shorter tradition in comparison with marketing practice in the private sector, and civil servants often need radical changes in their attitude and working methods (Buurma, 2001).

Overall, results of this study suggest that depending on the perceptions of managers, national and nature parks in the Republic of Croatia can be categorized into three groups with different characteristics regarding the level of application of marketing management, as shown in Table 3.

a) Group 1 - "Marketing - minded" parks are parks where the role of marketing and marketing management is recognized. The current level of their implementation demonstrates potentials for increase. Using available yet inadequate financial and human resources for marketing, managers strive to advance in the application of approaches that will merge tourism with sustainable development and enable integration with other stakeholders in the environment. In this way, achieving greater competitive advantage and building both the image of parks and Croatia as a tourist destination is being approached.

b) Group 2 - Parks lacking resources for marketing activities are those parks whose managers understand the need for active marketing and marketing management but do not have adequate resources for the implementation (which is mostly due to the park's specificities - size, seasonality in parks operations and alike). Managers in the parks belonging to this group are particularly interested in launching different joint initiatives that can improve the status of a park in a tourism offer. They expect that the umbrella brand "Parks of Croatia" will be of great help to them in the future tourism valorisation and business.

c) Group 3 - Conservative parks, those that are primarily focused on the protection and conservation of natural resources. Tourism and integration with other subjects in the environment for the purpose of creating the offer and building the image of the destination are considered as necessary activities that cannot be avoided. However, it is encouraging that managers in parks where such an approach prevails positively look on the umbrella brand as a way to help them deal better with the "imposed" situation of economic activities in the parks.

As one very interesting and even the most important finding of this study can be considered a fact that, regardless of the 
differences that managers attribute to the role and importance of marketing and marketing management, the umbrella brand approach is found to be a desirable and good way to improve parks' business in terms of enabling achieving better business results, education and professionalization of marketing experts and integration with other stakeholders in the environment.

\section{Conclusion and recommendations}

Successful marketing management should enable harmony between the park's nature conservation and tourism valorisation. Park managers should strive for sustainability and visitors' satisfaction in the continuously changing, demanding tourism market environment. Visitors are in search of highquality service and an authentic, memorable experience. Since it is often mistakenly considered that parks are areas in which human activity is not allowed, it is extremely important to educate visitors about the importance of preserving the natural beauty as well as about the potential hazards in case of non-compliance with the instructions. The proactive marketing approach is needed for the creation of competitive, environmentally responsible park services, which will offer increased opportunities for fostering an image of a country as a tourist destination.

This paper has discussed how managers currently perceive managing marketing in national and nature parks in the Republic of Croatia. Based on the findings, managers are encouraged to embrace more strategically planned marketing approaches and activities in order to gain advantages, commercially and with the aim of sustainability. There is plenty of room for different, new services and approaches that might contribute to achieving better results regarding the number of visitors and nature conservation, and strengthening the image of Croatia as a tourism destination.

\section{Theoretical and managerial implications}

The results of the study have relevance for theory and practice. The contribution to the theory and the existing literature consist of:

a) this is the first study that enables insight and provides some evidence into the umbrella branding approach, its implementation, and potential advantages in the frame of the marketing management of national and nature parks.

b) the study deepens and enhances the understanding of the topic with the results from the new research setting - national and nature parks in the CEE, Croatia.

As far as the implications for practice is concerned, parks should be more focused on marketing and invest in the marketing education and training of their employees who are mainly biologists, foresters and agronomists. Park managers should be capable of taking care of natural, economic, cultural and social dimensions of park values simultaneously. More emphasis should be given to the continuous care of aspects such as visitors' satisfaction, perceived service quality, the umbrella brand fit. The existing umbrella brand should help park managers to be aware of values which parks have to and could offer, and which their competitors (other destinations) do not have or offer.

Special attention should be paid to the choice of the associations that form the brand values and to guidelines on how to make their consistent and synergetic use across specific attractions and services of parks. Emphasizing selected, unique characteristics through the umbrella brand communication would certainly help to achieve better competitive positioning in the minds of internal and external audiences, not only of the parks as special places but also of Croatia as a tourism destination as a whole. The positive effects of joint advertising activities under the umbrella brand in the tourism industry are evident from the initiative by Croatian National Tourist Board, which conducts such activities for "Croatia - Full of Life" brand platform (Croatian National Tourist Board, 2019).

\section{Research limitations and future research}

Considering these results in the context of the research limitations is important. Findings depict one employee's perspective (park director or person responsible for marketing) that is not necessarily shared by the rest of the employees. As only one informant per park took part in the interview, findings suffer from single informant bias (Phillips, 1991). Another limitation relates to the subjective nature of 
data (the perceptions of respondents). Although not generalizable, results are indicative. Future academic research is needed and should be directed towards research of, e.g. opinions and attitudes of visitors, the motivation behind the choice of a particular park, about their expectations and perceptions, etc. Future research could also be developed by examining the level and quality of relationships among managers of different parks, as well as other topics related to their cooperation.

\section{References}

Archer, D., \& Wearing, S. (2002). Interpretation and marketing as management tools in national parks: Insights from Australia. Journal of Retail \& Leisure Property, 2(1), 29-39.

Baltic Sea Region Programme, (2012). Marketing Strategy \& Branding Concept of Parks \& Benefits. November 22, 2016. URL: http://bit.ly/2fYkYMQ (Accessed on 19.01.2018).

Barić, D., Anić, P., \& Macias Bedoya, A. (2016). Segmenting protected area visitors by activities: A case study in Paklenica National Park, Croatia. European Journal of Tourism Research, 13, 193-121.

Bosetti, V., \& Locatelli, G. (2006). A Data Envelopment Analysis Approach to the Assessment of Natural Parks' Economic Efficiency and Sustainability. The Case of Italian National Parks. Sustainable Development, 14, 277-286.

Buurma, H. (2001). Public policy marketing: marketing exchange in the public sector. European Journal of Marketing, 35(11/12), 1287-1302.

Cater, E.A. (2000). Tourism in the Yunnan Great Rivers National Parks System Project: Prospects for sustainability. Tourism Geographies, 2(4), 472-489.

Croatian National Tourist Board (2019). HRK 10 million for additional marketing and PR activities. URL: https://www.htz.hr/enGB/press/press-releases/hrk-10-millionadditional-marketing-and-pr-activities (Accessed on: 11.03.2019.)

Datzira-Masip, J., \& Poluzzi, A. (2014). Brand architecture management: The case of four tourist destinations in Catalonia.
Journal of Destination Marketing \& Management, 3, 48-58.

Daymon, C., \& Holloway, I. (2002). Qualitative Research Methods in Public Relations and Marketing Communications, Routledge.

Decrop, A. (1999). Triangulation in qualitative tourism research. Tourism Management, 20(1), 157-161.

Deffner, A., \& Metaxas, T. (2009). Marketing the National Marine Park Image in Greece. Anatolia: An International Journal of Tourism and Hospitality Research, 20(2), 307-328.

Dooley, G., \& Bowie, D. (2005). Place brand architecture: Strategic management of the brand portfolio. Place Branding, 1(4), 402419.

Douglas, A. (2016). A customer-focused approach to distribution: the case of SANParks. South African Journal of Economic and Management Sciences, 19(3), 413-431.

Eagles, P. F. J. (2014). Research priorities in park tourism. Journal of Sustainable Tourism, 22, 528-549.

Eagles, P.F.J., \& McCool, S.F. (Eds.) (2002). Tourism in National Parks and Protected Areas. Planning and Management. Oxon: CABI Publishing.

Erdem, T. (1998). An empirical analysis of umbrella branding. Journal of Marketing Research, 35(3), 339-351.

Flagestad, A., \& Hope, C. A. (2001). "Scandinavian Winter"; Antecedents, concepts and empirical observations underlying a destination umbrella branding model. Tourism Review, 56(1-2), 5 - 12.

Gilmore, A., \& Simmons, G. (2007). Integrating sustainable tourism and marketing management: Can national parks provide the framework for strategic change? Strategic Change, 16(5), 191-200.

Gnoth, J. (2007). The structure of destination brands: leveraging values. Tourism Analysis, 12(5-6), 345-358.

Hankinson, G. (2010). Place branding research: A cross-disciplinary agenda and the views of practitioners. Place Branding and Public Diplomacy, 6(4), 300-315.

Haukeland, J. V. (2011). Tourism stakeholders' perceptions of national park management in Norway. Journal of Sustainable Tourism, 19(2), 133-153. 
Hsieh, H.-F., \& Shannon, S. E. (2005). Three Approaches to Qualitative Content Analysis. Qualitative Health Research, 15(9), 1277-1288.

Hogenauer, A. K. (2002). Marketing national parks: oxymoron or opportunity? In Sh. Todd, (Ed.), Proceedings of the 2001 Northeastern Recreation Research Symposium (pp. 53-59), PA, US, U.S. Department of Agriculture, Forest Service, Northeastern Research Station.

IUCN, (2018). International Union for Conservation of Nature. August 7th. URL: www.iucn.org.2018 (Accessed on 22.08.2018).

Iversen, N. M., \& Hem, L. E. (2008). Provenance associations as core values of place umbrella brands: A framework of characteristics. European Journal of Marketing, 42(5/6), 603-626.

Kim, S.S., Lee, C-K., \& Klenosky, D.B. (2003). The influence of push and pull factors at Korean national parks. Tourism Management, 24(2), 169-180.

Koliouska, C., \& Andreopoulou, Z. (2013). Assessment of ICT Adoption Stage for Promoting the Greek National Parks. Procedia Technology, 8, 97-103.

Kooli, K., Cai., H., Tang, X., Beer, C., \& Wright, L. T. (2016). Better together? A hospitality case for umbrella branding. Journal of Business \& Industrial Marketing, 31(8), 1004-1016.

Kruger, M., \& Saayman, M. (2010). Travel motivations of tourists to Kruger and Tsitsikamma National Parks: a comparative study. South African Journal of Wildlife Research, 40(April), 91-102.

Lune, H., \& Berg, B. L. (2017) Qualitative Research Methods for the Social Sciences - $9^{\text {th }}$ edition. Pearson Education Limited.

Mayer, M., Müller, M., Woltering, M., Arnegger, J., \& Job, H. (2010). The economic impact of tourism in six German national parks. Landscape and Urban Planning, 97(2), 73-82.

Miklós-Thal, J. (2012). Linking reputations through umbrella branding. Quantitative Marketing and Economics, 10(3), 335374.

MINT, (2018). More and more people visiting 19 Croatian national and nature parks. URL: https://mint.gov.hr/news-11455/more -and-more-people-visiting-19-croatiannational-and-nature-parks/14354 (Accessed on 13.08.2018).

Nan Hwang, S., Lee, C., \& Chen, H-J. (2005). The relationship among tourists involvement, place attachment and interpretation satisfaction in Taiwan's national parks. Tourism Management, 26(2), 143-156.

Nogueira, S., \& Pinho, J. C. (2015.) Stakeholder Network Integrated Analysis: The Specific Case of Rural Tourism in the Portuguese Peneda-Gerês National Park. International Journal of Tourism Research, 17(4), 325-336.

Ortega, E. (2009). Exploratory analysis of the national parks of Spain and New Zealand. Identifying practice of improvement. In: Celant, A. and Iturralde, T. (ed.), Creativity and survival of the firm under uncertainty, XVIII International Congress of the European Academy of Management and Business Economics (AEDEM), Rome (Italy), European Academics Publishers, ISBN: 13: 978-84-692-5174-4. (pp. 1-11) Published in CD.

Pine, B. J., \& Gilmore, J. H. (1998). Welcome to the Experience Economy. Harvard Business Review, July/August, 97-105.

Phillips, L.W. (1991). Assessing Measurement Error in Key Informant Reports: A Methodological Note on Organizational Analysis in Marketing. Journal of Marketing Research, 18(4), 395-415.

Reid, M., Wearing, S., \& Croy, G. (2008). Marketing of Protected Areas as a Tool to Influence Visitors Pre-Visit Decisions. Technical Report. The Gold Coast, Queensland: Sustainable Tourism Cooperative Research Centre. URL: https://bit.ly/2oM33Pm (Accessed on 16.02.2018).

Ren, C., \& Blichfeldt, B. S. (2011). One Clear Image? Challenging Simplicity in Place Branding. Scandinavian Journal of Hospitality and Tourism, 11(4), 416-434.

Schmitt, B. (1999). Experiential Marketing: A New Framework for Design and Communications. Design Management Journal, (40 th Anniversary issue, 2015), 10(2), 19-26.

Schwartz, Z., Stewart, W., \& Backlund, E.A. (2012). Visitation at capacity-constrained 
tourism destinations: Exploring revenue management at a national park. Tourism Management, 33(3), 500-508.

Sharpley, R., \& Pearce, T. (2007). Tourism, Marketing and Sustainable Development in the English National Parks: The Role of National Park Authorities. Journal of Sustainable Tourism, 15(5), 557-573.

Smyth, D. (2001). Joint management of national parks in Australia. In R. Baker, J. Davies and E. Young (Eds.), Working on Country - Contemporary Indigenous Management of Australia's Lands and Coastal Regions. Oxford: Oxford University Press.

Snow, C.C., \& Thomas, J.B. (1994). Field research methods in strategic management: contributions to theory building and testing. Journal of Management Studies, 31(4), 457-480.
Wang, Y., \& Krakover, S. (2008). Destination marketing: competition, cooperation or coopetition? International Journal of Contemporary Hospitality Management, 20(2), 126-141.

Yellowstone Country Montana (2011). Marketing Plan 2011-2012. 22 November, 2016. URL: http://bit.ly/2gxu6vp (Accessed on 22.05.2018).

Therkelsen, A., \& Halkier, A. (2008). Contemplating Place Branding Umbrellas. The Case of Coordinated National Tourism and Business Promotion in Denmark. Scandinavian Journal of Hospitality and Tourism, 8(2), 159-175.

Uredba o upravljanju nacionalnim parkovima, NN 59/1991. URL: https://narodnenovine.nn.hr/clanci/sluzbeni/1991_11_59_ 1574.html (Accessed on 03.10.2018). 